\title{
Editorial
}

\section{Standards: A Scientific Journal of Standardization}

\section{Shu-Kun Lin}

check for

updates

Citation: Lin, S.-K. Standards: A Scientific Journal of Standardization. Standards 2021, 1, 1. https://doi.org/ 10.3390/standards1010001

Received: 25 January 2021 Accepted: 25 January 2021 Published: 27 January 2021

Publisher's Note: MDPI stays neutral with regard to jurisdictional claims in published maps and institutional affiliations.

\section{Copyright: (C) 2021 by the author.} Licensee MDPI, Basel, Switzerland. This article is an open access article distributed under the terms and conditions of the Creative Commons Attribution (CC BY) license (https:// creativecommons.org/licenses/by/ $4.0 /)$.
MDPI, St. Alban-Anlage 66, CH-4052 Basel, Switzerland; lin@mdpi.com

We first planned to launch the journal Standards in 2012 and obtained ISSN 2305-6703 for Standards (Basel). After a very lengthy preparation, we now formally declare the start of this journal.

There are at least three scientific journals on standardization, assessment, or verification [1-3]. The Journal of Research of the National Institute of Standards and Technology [3] accepts contributions from NIST staff only and publishes peer-reviewed research articles, in addition to dataset and software articles, tutorials, and tech transfer briefs [3].

Standards (ISSN 2305-6703) will be an international scientific open access journal on standardization, inspection, verification, certification, testing, quality control, rating, and all other related topics. It will cover all scientific, engineering, and technology fields.

As with the running of other MDPI journals, we will maintain a fast and rigorous peer review process [4] for this new journal. We hope that you will enjoy publishing with us.

\section{References}

1. Geostandards and Geoanalytical Research (ISSN/eISSN: 1639-4488/1751-908X). Available online: https:/ / onlinelibrary.wiley.com/journal/1751908x (accessed on 21 January 2021).

2. Computer Standards \& Interfaces (ISSN/eISSN: 0920-5489/1872-7018). Available online: https://www.sciencedirect.com/journal/computer-standards-and-interfaces (accessed on 21 January 2021).

3. Journal of Research of the National Institute of Standards and Technology (ISSN/eISSN: 1044-677X/2165-7254). Available online: https:/ / www.nist.gov/nist-research-library/journalresearch-nist (accessed on 21 January 2021).

4. List of Publons Reviews for Journals and Conferences. Available online: https://publons.com/ journal/?order_by=reviews (accessed on 21 January 2021). 